\title{
Antzinako Ostatu-Etxe izatetik Bigarren Hezkuntzako Institutu izatera. Bergarako Mintegiaren historia ikasleen ikuspegitik (1776-1860)
}

\author{
Álvaro Chaparro Sainz \\ Institut Universitaire de France \\ Université de Nice \\ Igor Camino Ortiz de Barrón \\ Hezkuntzaren Teoria eta Historia Saila \\ Gasteizko Irakasleen Unibertsitate Eskola \\ Euskal Herriko Unibertsitatea (UPV/EHU)
}

DOI: $10.1387 / \tan t a k .14460$

GAKO-HITZAK: Bergara, Gipuzkoa, mintegia, Bigarren Hezkuntza, institutua

\section{SARRERA}

Aurkezten dugun lana azkeneko urteotan jorratzen ari garen ikerketalerro batean sartzen da, aktoreengan zentratzen den hezkuntzaren historia sozialaren esparruan; ondorioz, historiografiako ikuspegi instituzionalagoetatik aldentzen $\mathrm{da}^{1}$. Honela, hezkuntza ikastegiak, barruan biltzen zituzten lagunengandik abiatuta aztertu behar direla defendatzen dugu; haiei protagonismoa eman nahi diegu, beren ibilbideak aztertzeak ikastegi pedagogikoen zergatia eta funtzionamendua hobeto ulertzea ahalbidetuko baitu.

Bergarako Errege-Mintegiak hezkuntzaren historian aritzen garen ikerlarion atentzioa maiz erakarri duen ikastegia da. Antzinako Erregimenaren erreferentziazko hezkuntza ikastegia izan den neurrian, hari buruzko ikerlanek Espainiako Ilustrazioaren testuinguruan kokatu dute, XVIIII. mendean Noble Mintegien bidez aurrera eraman zen hezkuntza berrikuntzaren ildo-

${ }^{1}$ Imízcoz, J.M. eta Chaparro, A. (Coord) (2013). Educación, redes y producción de élites en el siglo XVIII. Madril: Silex. 
tik, edota Espainiako monarkiak bultzatuta Herriaren Adiskideen Elkarte Ekonomikoek egindako lan kulturalaren eta pedagogikoaren ildotik. Hainbat hamarkadatan zehar egindako lanek erakunde pedagogiko honen gaineko ezagutzan sakontzea ahalbidetu dute ${ }^{2}$. Era berean, izaera orokorragoa erakusten duten Espainiako Hezkuntzaren Historiari buruzko lan guztiak bat datoz Bergarako Mintegia hezkuntza ikastegi nagusietakoa dela onartzen. Hala ere, lan horietan haustura kronologiko bat agertzen da, gehienetan zatikako analisia egiteko asmoz justifikatua, baina ikuspegi orokorra eskuratzea zaildu egiten duena; zatikako analisi horrek ikastegiaren sorrera erakusten du abiapuntu, eta Mintegiak bere nortasuna - eta jatorrizko erakundearekiko paralelismoa - galtzen duen arte iritsi ohi da.

\subsection{Helburuak eta abiatzeko hipotesia}

Aurretik esandakoa kontuan hartuta, lan honen helburuak jarraian zerrendatzen direnak dira:

- Bergarako Mintegiaren ikuspegi orokorra ahalbidetzea: asmoa azken hamarkadetan egindako ikerlanek erakutsitako haustura kronologikoa gainditzea da; une ezberdinen araberako aldaketa esanguratsuak erakutsi baditu ere, ikastegi bera da aztertzen dena eta, alde horretatik, garrantzitsua da orain arte gehienetan gauzatu ez den analisi oso bat egitea, ikuspegi ekonomiko, sozial, pedagogiko, politiko eta kulturala barne hartzen dituena.

- Ikastegian biltzen ziren lagunei protagonismoa ematea: erakundearen ikuspegi osoa ahalbidetzeko, horretan biltzen ziren lagunengan oinarritzea ezinbestekoa da, haiek ordezkatu baitzuten hezkuntza ikastegiaren alde bizia eta, haien bidez, era esanguratsuagoan ezagutu ahal izango dira horren bizipenak eta gainditu behar izan zituen gorabehera historikoak. Alde bizi horren barruan, ikasleak ez ezik, zuzendariak, irakasleak, langileak, laguntzaileak eta abar ere: guztiek, era batean edo bestean, hezkuntza erakundeak aurrera egitea ahalbidetu zuten. Planteamendu hau, hezkuntzaren historia sozialaren esparruan eginda, azken hamarkadetan erakunde administratiboen gainean egindako ikerlanen testuinguru historiografikoan kokatzen $\mathrm{da}^{3}$.

2 Jarraian lanik adierazgarrienak aipatuko ditugu: Aguilar, 1980; Caballer, 2009; Cano, 2000; Chaparro, 2011; De Felipe, 1993; Iriarte, 1953; San Larrañaga, 1991; Letamendia, 1987; Martínez, 1972; Mendiola, 1961; Recarte, 1990; Silván, 1977; Tellechea, 1977; Yoldi, 1945; Yrizar, 1945; Caballer, 2008; Pellón eta Llombart, 1998; Camino, 2012.

${ }^{3}$ Laburpen moduan: Dedieu, J.P. (2000). Procesos y redes. La historia de las instituciones administrativas de la época moderna, hoy, in Castellano, Dedieu, J.P. eta López-Cordón, M.V. (edit.), La pluma, la mitra y la espada. Estudios de Historia Institucional en la Edad Moderna. 13-30. 
- Ikasleei arreta berezia eskaintzea: alde bizi horretako eragileen artean, ikasleengan zentratzea erabaki dugu, ikastegiaren alderik esanguratsuenetakoa eta hezkuntza-proiektu baten eta politika pedagogiko eta kultural baten isla eta emaitza baitira. Hala ere, egoitzan bizi ziren matrikulatutako ikasleen datuak - seminaristak - kontuan hartu direla zehaztu beharra dago, Ordenantzetan «barneko ikasle» ${ }^{4}$ deituak; hauez gain, iturriek erakusten duten bezala, kanpoko ikasleak ere bazeuden, baina ezinezkoa izan da horien kuantifikazio zehatzik topatzea. Adibide gisa, igandeetan irakasten zen doktrina erlijiosoaren kasuan, 1818ko Ordenantzek zehazten dute hori barneko ikasleentzat soilik eskaintzen zela, ezinezkoa ikusten baitzen eskolara joaten ziren kanpoko ikasle guztiak ere egotea ${ }^{5}$.

Abiatzeko hipotesiei dagokienez, lehenengoak Bergarako Mintegiaren garapena Erregearenganako zerbitzu testuinguruan kokatzen du; hipotesi honen arabera, erakundeak une oro jokatuko luke organorik gorenaren interesen arabera. Hori horrela izanik, XVIII. mendearen bukaeran, monarkia gobernatzeko prestaturik egon zitezkeen eragileen beharra azpimarratzen zen; agerikoa zen gero eta burokratizatuagoa zen gobernua administratzeko trebatuta egongo ziren eragile teknikoen beharra ${ }^{6}$. Hamarkada batzuk beranduago, gertakari historiko ezberdinek bultzatuta herrialdeak eduki zuen eraldaketaren ondorioz, gobernuaren beharrak ere aldatu egin ziren: ondorioz, irakaskuntza-esparru berri bat eratu zen, eta bertan herrialdearen industrializatze prozesua prestatzeko pertsonak trebatzea zen helburua. Une horretara ailegatuta, teknikoen beharra murriztu zen heinean, handitu zen ingeniariena.

Bigarren hipotesi batek familiek ikastegiei erakutsitako fideltasunarekin erlazionatzen da. Honek hainbat hezkuntza erakunderen gaineko hausnarketa kolektibo baten beharrarekin erakusten du zerikusia; horien artean hasiera batean lotura falta egon daitekeela eman arren, frogagarria da - erakutsi zituzten izenetatik eta kokalekuetatik haratago joanda - erakunde horiek eskutik helduta abiatu zirela eta testuinguru historikoari egokitzeko antzeko ibilbidea erakutsi zutela. Esandakoaren adibide nagusi bezala, San Isidroko Errege Ikasketak, Madrilgo Nobleen Errege Mintegia, Unibertsitate Zentrala eta Madrilgo Unibertsitate Konplutensea aipa daitezke; erakunde hauek guztiak erlazionatzen zituen gidalerro bat agertzen da, eraikin fisikoetatik harago doana eta, finean, garrantzitsuena den horretara ailegatzen dena: pertsonengana. Alde horretatik, interesgarria da egiaztatzea familia batzuek beren ondorengoak erakunde berberetan matrikulatzen zituztela, nahiz eta horien izena edo profila aldatu; pentsatzekoa

\footnotetext{
${ }^{4}$ Alumno interno, jatorrizko dokumentuan..

5 Bergarako Nobleen Errege Mintegiaren gobernurako Ordenantzak, 1818.

6 Dedieu, J.P. (2005). La muerte del letrado in Aranda, F.J. (Koord.). Letrados, juristas y burócratas en la España Moderna. Cuenca: Universidad de Castilla La Mancha.
} 
da kasu horietan edukitzailea zela beren atentzioa erakartzen zuena, eta ez hainbeste edukia.

\subsection{Erabilitako iturri nagusiak}

Lan honek erakundean hainbat une historiko garrantzitsutan sortutako dokumentu ofizialak hartu ditu iturri: Ordenantzak, Berriak, Diskurtsoak edo Memoriak. Horietako gehienak Administrazioaren Artxibategi Orokorrean (AAG) eta Valladolideko Unibertsitate Artxibategian (VUA) kontsultatu dira. Jarraian zerrendatzen dira ikerlan honen ardatzak izan diren orri-sortak:

- AAG, 6541. orri-sorta:

- Industria ikasketa berrien memoria (1852).

- Bergarako Industria Eskolaren memoria (1855-56).

- Bergarako Zientzia eta Industria Mintegiaren komunikazioak (1851-1860).

- VUA, 1975. orri-sorta:

- Bergarako Zientzia eta Industria Mintegia. Matrikulazio zerrendak.

Lehen mailako iturri hauek erakundearen garapena zehazki ezagutzea ahalbidetzen dute. Bergarako Hezkuntza erakundeak, bere historian zehar, izendapen ezberdinak eta gobernu organo aldaketak erakutsi zituen; Euskalerriaren Adiskideen Elkarteak - Mintegiaren sortzailea izan zena- kudeatua izatetik, Madrilgo Gobernuaren menpeko kudeaketara pasatu zen. Era horretan, Erregea buru agertzen zen arren, erakundearen kontrol zuzena Estatuko Idazkariaren esku geratzen zen.

\section{BERGARAKO MINTEGIA: IZENETATIK ETA GIZONENGANDIK ABIATZEN DEN HISTORIA}

Bibliografia-berrikusketak erakusten duen bezala, gutxi dira Bergarako erakunde ilustratuaren gaineko ikuspegi zabala eskaintzen saiatu diren ikerlanak. Hasteko, saiakera hori egin dutenen artean, Emilio de Felipek Euskalerriaren Adiskideen Errege Elkartean sartzeko aurkeztu zuen ikerlana aipatu behar dugu: «Los cien nombres del Seminario de Bergara (1776-1873)» ${ }^{7}$. Egileak, jatorrizko testuak eta ikasturte hasieran eman ohi

${ }^{7}$ De Felipe, E. (1993). Los cien nombres del Seminario de Bergara (1776-1873). Nuevos Extractos de la Real Sociedad Bascongada de los Amigos del País, Boletín de la Real Sociedad Bascongada de los Amigos del País, 6-G, 13-69. 
ziren diskurtsoak baliatuz, sakon aztertzen du Bergarako erakundeak edukitako izenak. Horren emaitza erakundearen ezagutza fidagarria ahalbidetzen duen ikerlan bat da.

Ikuspegi kronologiko zabalaren ildotik jarraituz, Inés Pellón-en eta José Llombart-en lana aipatu behar dugu, zeinak Bergarako Mintegian ikasi zuten Errioxako ikasleen ibilbidea aztertzen baitu ${ }^{8}$. Lan horren hasieran, Errioxako ikasleek aipatutako erakundean zuten pisua frogatzeko asmoz, egileek azterketa kuantitatiboa egiten dute; ikasle talde zehatz batekin erlazionatzen den lana izanik, lehen aldiz zenbaki orokor batzuk eskaintzearen meritua onartu behar zaio, Bergarako Mintegiaren lehen ikuspegi osoa erakutsiz ${ }^{9}$.

Bergarako hezkuntza erakundeak izen aldaketa ugari eduki bazuen ere, beti koordenada berberen menpe mantendu zen, bere sorrerarekiko fideltasuna erakutsiz. Izen aldaketa horiek hobeto ulertzen lagun dezaketen arrazoien artean, erakundearen barne-kudeaketan emandako aldaketak, gerra-gertakarien ondorioz gertatutako behin-behineko itxierak, ikastegiaren profil pedagogikoaren aldaketak eta finantziazio arazoak nabarmentzen dira. Azken horiek, azkenean, gaindiezinak suertatu ziren.

Bergarako Mintegia zabaldu baino lehen, etorkizun sendoa eta eraginkorra lortzeko hezkuntza egitura bat egonkortzeko saiakera aldarrikatzen zen. Horretarako, Euskalerriaren Elkartearen sortzaileek beren ondorengoak baliatu zituzten; beren hezkuntza prozesua Eskola Patriotikoa delakoan aurrera eraman zuten, Mintegiaren aurrekaria izan zen eskolan hain zuzen. Euskalerriaren Errege Elkartearen Akta Liburuetan aztertutakoaren bidez, hasierako praktika horietako batzuk berreskuratu ahal izan dira; honela, 1766ko azaroaren 4an bildutako Asteko Batzarrean, zenbaki-bazkideak eta «On Ramón de Munibe, On Antonio María de Munibe eta On Fausto Antonio de Corral (haiekin batera, baita ere, orduan 17 urte zituen On Santiago de Samaniego bildu zen, literatura-jardueretan parte hartu nahi izan zuena) ikasleek topo egin zuten» ${ }^{10}$. 1776ko irailaren 20an datatutako dokumentu batek «ikasleentzat, dirulaguntzak eskaintzen zituzten bazkideen semeentzat eta pupiloentzako pentsio-etxe baten ezarpena» proposatzen zuen. Testuak zioenez, aurreikusitako Mintegia gauzatu arte,

${ }^{8}$ Pellón, I. eta Llombart, J. (1998). La formación científica recibida en el Real Seminario Bascongado por los estudiantes riojanos in Español, Luis (Koord.) Matemática y región: La Rioja : sobre matemáticos y matemática en La Rioja. Logroño: Instituto de Estudios Riojano, 343-368.

${ }^{9}$ Ezin dugu ahaztu honako obra hau: Martínez, J. (1972). Filiación de los seminaristas del Real Seminario Patriótico Bascongado y de Nobles de Vergara. Donostia: Euskalerriaren Adiskideen Elkartea. Obra hau erreferentzia nagusi bat izan da aurkezten dugun lanerako.

${ }_{10}$ Gipuzkoako Euskalherriaren Adiskideen Elkartearen Akta Liburua (1766-1783). Data: 22/10/1766,1. Egileen itzulpena. 
«pentsio-etxeak barne baliabidea izateko asmoa zuen, ikasleak era egokian eta seguruan zainduta egon zitezen» ${ }^{11}$.

Martín de Errok, aipatutako azken data horretan Letra Onen maisua zenak, «pentsio-etxea» proposatzen zuen testua erredaktatu zuen; bertan, hezkuntza, egoitza eta zaintza eskainiko zitzaien «Euskalerriaren Elkartearen ikasleei... eta bazkideak ziren senideen zaintzapean zeuden gazteei». Finean, testuak zioenez, "Mintegia gauzatu arte mantenduko zen barne baliabidea izango zen» ${ }^{12}$. Hezkuntza egitasmo honek ikastegiaren hasierako pautak jasotzen zituen.

Azkenean, 1776ko urrian, Bergarako Errege Mintegi Patriotikoak ateak zabaldu zituen. Lehehengo urtean 17 seminarista bakarrik zeuden ikastegian, horietatik \% 70 euskal probintzietatik eratorritakoa (17tik 13); zortzi urte beranduago, 1784an - Mintegian matrikulatutako seminarista gehien erakutsi zuen urtea-, 41 matrikula berrietatik, euskal probintzietatik eratorritako ikasleria \% 7 soilik zen, \% 41 Amerikatik, \% 22 Andaluziatik, \% 15 euskal probintzien inguruko probintzietatik eta, azkenik, beste $\% 15$ Iberiar penintsulako beste lurralde batzuetatik. Bergarako Mintegiak, ikasleriaren jatorriarekin erlazionatutako datuei erreparatuz, hamar urte baino gutxiagoan, eraldaketa esanguratsua erakutsi zuen: euskal jatorriari erreparatuz gero, \% 70tik \% 7ra pasatu zen; hona beste datu esanguratsu batzuk: ikastegiaren sorreraren urtean Amerikatik \% 6 (ikasle bat) soilik etorri zen, eta zortzi urte beranduago, 17 seminarista (\% 41) heldu ziren Atlantikoaz bestaldetik.

Lehendabiziko urte hauetan jazo zen joera positibo honek laster aurkitu zuen etorkizuna baldintzatu zuen arazo bat: Xabier María de Muniberen - Peñaflorida Kondearen - heriotza, 1785an; ikastegiko zuzendaria izateaz gain, hezkuntza egitasmo ilustratuaren erreferentzia nagusia zen. Galera pertsonal handia izan arren, funtzionamendu praktikoaren ildotik ikasleek ez zuten horren ondorio zuzenik sumatu, ikastegia oso egoera onean baitzegoen: matrikula kopuru altuak finantziazioari aurre egitea ahalbidetzen zuen, ikastegiko oparoaldia bermatuz.

Laurogeita hamarreko hamarkadan, Mintegiaren lehen krisialdia jazo zen; ikastegiak, Konbentzio Gerraren ingurumarian tropa frantziarrak Bergaran sartu zirenean, ateak itxi behar izan zituen. Ikastegiak lau urte pasa behar izan zituen erbestean -Gasteizen-, eta ondorioz ikasle eta irakasle askok ikastegia laga zuten, hezkuntza egitasmoaren garapen aukerak bertan behera utziz. Euskalerriaren Adiskideen Elkartearen bazkideek, beste behin, indar guztiak erabili behar izan zituzten ikastegia berriz zabaltzeko. Gerra egoera igarota, egitasmoa berreskuratu zen eta ikasgelak 1798an za-

11 (Behin behineko Eskolari buruzko berria, 13. or.). Egileen itzulpena.

12 Euskalerriaren Adiskideen Elkarteak 1776ko irailaren 20an hartutako akordioaren ondorioz ezarri nahi duenBehin Behineko Eskolari buruzko berria. Egileen itzulpena. 
baldu ziren hazkunde berri bat lortzeko asmoz: «la paz dejará a los americanos expeditos los caminos, que ahora cierra la Guerra y todo debe hacernos esperar un numerosísimo concurso de seminaristas en breves años» ${ }^{13}$.

1799ko dokumentu batek zehaztasun handiz deskribatzen du Mintegiaren egoera guda pasatu ostean: «había ocasionado considerables deterioros al edificio, los Gabinetes de Física, Química y Minerología y los Laboratorios habían quedado saqueados, y destrozados; los fondos del Seminario eran cortísimos, deducidas sus cargas, y los de la Sociedad no alcanzaban a los gastos precisos de Juntas, premios, extractos y dotaciones de las escuelas de Dibujo, los profesores antiguos estaban ya en otros destinos o más ventajosos o más seguros. Las insuficiencias de los fondos estables, y la contingencia del sobrante de Pensiones de Seminaristas debía dificultar la venida de otros ${ }^{14} \gg$.

Ikastegiaren itxiera gertatu aurretik, hezkuntza egitasmoak ez zuen antzekotasun handirik erakusten bi hamarkada lehenago ia era esklusiboan Elkartearen semeentzat eskaintzen zenarekin. Mende aldaketatik gertu egonda, Bergarako Mintegia «munduko lau aldeetatik... gazteri ugari» ${ }^{15}$ jasotzen zuen ikastegia zen. Berriz zabaltzeko erabakia behin hartuta, arduradunek, Mintegia berregituratzeko asmoz, gerra baino lehen ikastegian ziharduten irakasleekin harremanetan jarri ziren gutun bidez. Ordurako, hala ere, horietako askok beren bizitza antolatua zuten gerra-lurraldeetatik urrun. Berriz zabaltzearen arrakasta, lortuko zen matrikula kopuruaren menpe geratuko zen; hala ere, gazteak jaso ahal izateko, ikastegia berriz ere zabaltzea ezinbestekoa zen. Hedabide-oihartzun handiagoa lortzeko asmoz, Gaceta de Madriden iragarri zen ikastegiak bere martxa berreskuratzen zuela. Euskal ilustratuek gogotsu lan egin zuten egitasmoaren egonkortasuna ziurta zezaketen 24 matrikulak eskuratzeko.

Guztiarekin, 1798an, «Mintegia lau ikaslerekin bakarrik ireki zen..., egun batzuk pasata beste bost sartu ziren eta, urte erdia igarota, dozena bat ikasle zeuden» ${ }^{16}$. Zabaldu ondorengo hilabeteetan eduki zituzten arazo ekonomikoak «Juros de Temporalidades» izeneko organoari esker gainditu ahal izan ziren; Juan de Arios-en presentzia horretan - Euskalerriaren Elkartearen bazkidea-, oso lagungarria izan zen, haren bitartekotzari esker Mintegiaren aldeko laguntza ekonomiko batzuk eskuratu baitziren. Ikasturtea ikasleen azterketen defentsa publikoarekin amaitu zen; Gaceta de Madriden azterketen berri emateak ikastegiak berreskuratutako normal-

13 Idem, 13-14 orr.

14 «Discurso acerca del restablecimiento, progresos y esperanzas del Real Seminario Patriótico Bascongado», Euskalerriaren Adiskideen Elkarteak Bilbon 1799ko uztailaren bukaeran egindako Batzar Nagusietan irakurria.

15 Idem, 5. orr. Egileen itzulpena.

${ }^{16}$ Idem, 6. orr. Egileen itzulpena. 
tasunaren berri eman zuen eta, ondorioz, aurrerantzean areagotu egin ziren informazio eta matrikula eskaerak ikasturte berriari begira.

Zailtasun aroa gaindituta, honela ikusten zen ikastegiaren egoera 1799ko uztailean emandako hitzaldian: «un establecimiento político - moral-científico que habiendo tenido principios tan pobres, tan pequeños, tan poco sólidos, ve asentados sus cimientos en el corto término de 19 meses y promete, no solo una consistencia duradera, sino aumentos muy considerables» ${ }^{17}$. Hauexek ziren bertan ikasten zuten ikasleen irteera-profilaren ezaugarriak: "el amor a la Patria, y al Rey, a la honradez, y las obligaciones de todo ciudadano para con Dios, consigo mismo y con el resto de los hombres» ${ }^{18}$.

Zailtasunak zer-nolakoak izan ziren jakin arren, hitzaldi horrek uzten duen irakurketa egokitzat jo behar da, etorkizunerako egitasmoz beterik agertzen baitzen, iraganaren oinarriak berdin mantentzen baziren ere: Erregearenganako eta aberriarenganako zerbitzua, eta ikasleak etorkizunerako heztea balio zehatz batzuen arabera. Hitzaldian arazo ekonomikoen berri ematen zen: etorkizun hobea ziurtatzeko asmoz, iraganean egindako — eta oraindik kobratu gabeko - inbertsioei erreferentzia egiten zitzaien.

Kudeaketaren ikuspegitik, Carlos IV .aren erregealdian, 1804an, eta uztailaren 27ko Errege Aginduak lagunduta, Bergarako Mintegiak bere historiako aldaketarik garrantzitsuena bizi izan zuen: aipatutako urtean, ikastegiaren zuzendaritza Euskalerriaren Elkartearen arduradunen eskuetatik Madrilgo gobernuaren - beraz, Erregearen eta, praktikan, Estatuko Idazkariaren- eskuetara - pasatu zen. Testuinguru berri horretan, Erregeak izendatutako lehenengo zuzendaria Miguel de Lardizábal Uribe izan zen, aurretik Estatuko Idazkaritzan esperientzia erakutsi zuena eta Bigarren Idazkari Nagusi izatera ailegatu zena. Hala ere, Manuel Godoy-rekin edukitako liskar batzuen ondorioz, Miguel Lardizabal euskal probintzietara bidali, eta Mintegiko Zuzendari izendatu zuten.

1804. urteko dokumentu batek aurreko etaparekin alderatuta egongo ziren berrikuntzak zehazten zituen; ikastegian eskainiko ziren irakasgaien edukia aurkeztu ondoren, honako berrikuntza hauek iragarri ziren: «se abrirán las cátedras de griego, italiano y otras varias que conciernen a un Instituto de Segunda Enseñanza, gracia concedida por S. M.» ${ }^{19}$ Datu adierazgarri bezala, azpimarratzekoa da Erregeak zuzenean izendatutako lanpostuez sarituko zituela sei urtez beren karguan ziharduten Mintegiko ikuskariak, zerbitzu garrantzitsu bezain delikatua konsideratzen baitzen.

Urte horretan bertan, erakundearen izena lehen aldiz aldatu zen; izen berria «Real Seminario de Nobles» izan zen eta, gertari historikoen on-

\footnotetext{
17 Idem., 10. orr.

18 Idem, 11-12. orr.

19 Bergarako Udal Artxiboa, 3.04.01, C/095
} 
doriozko aldaketa batzuk kenduta, izen hori hainbat hamarkadatan zehar mantendu zen. Adibide bat jartzearren, José I.aren erregealdiak ekarritako frantsesen kontrolaren menpe, erakundeak «Liceo Vascongado» izena hartu zuen; Berrezartzearen garaian, Fernando VII.aren menpe, erakundeak 1804ko izena berreskuratu zuen. Izen hori, ordea, hirurteko liberalean berriz ere aldatu zen: Universidad de Provincia o Universidad de Segunda Enseñanza.

Hezkuntza egitasmoari dagokionez, 1818ko Ordenantzek iradokitzen zuten «ikasketen aukeraketa ez, uztea interesatu bakoitzaren familien borondatearen menpe; metodo egonkor baten beharra ikusten zen» ${ }^{20}$; ohar hau, ordea, ez zen jasotzen XVIII. mende bukaerako «Seminario Patriótico» delakoaren lehen testu ofizialetan. Datu adierazgarri bezala, azpimarratzekoa da Ordenantzen testuak ikasleen ezagutza mailari eta adinari erreparatzeko beharra jasotzen zuela; aurretik egindako lanetan ${ }^{21}$ egiazta daitekeen bezala, Euskalerriaren Elkartearen lehen gobernu garaian, bi faktore horiek ez ziren kontuan hartzen, eta horrek planteamendu berriari garrantzi berezia ematen zion. Ordenantza horien analisiarekin jarraituz, zehazten zuten Erregeak izendatu behar zituela zuzendaria, maisu nagusia, bigarren maisua, idazkaria eta ekonomoa; betetzeko posturen bat geratzekotan, Zuzendariak Erregeari hiru hautagai proposatzeko aukera zuen. Zuzendariak, era zuzenean, ikuskariak, arroparen arduraduna, sukaldaria eta ikastegiko beste morroiak izendatzeko ahalmena zuen.

1818ko Ordenantzek, 28. orrialdean, ikastegiaren premisa nagusi bat garbi azpimarratzen zuten: «la verdadera economía consiste en gastar únicamente lo necesario para que el establecimiento esté servido con la abundancia y brillo que requiere una casa de educación donde envían sus hijos las familias más distinguidas de la Monarquía»22. Aipatutako data horretan, Mintegiko ikasle sartu nahi zutenentzat eskatzen zen gutxiengo adinak ez zuen alderik erakusten 1776an eskatzen zenarekin; Bergarako ikastegian hezkuntza prozesua egin nahi zuen gazte orok zazpi eta hamairu urte bitarteko adina izan behar zuen. Eskakizun honez gain, etorkizuneko ikasle izateko, gurasoen eta aiton-amonen bataio eta ezkontza agiriak erakutsi behar ziren, eta baita aiton-amonenganaino iristen zen zuhaitz genealogikoa; eskakizunak ez ziren hor bukatzen, Ordenantzek beste batzuk ere zehazten zituzten: «una información auténtica recibida en el pueblo donde vivan o hayan vivido sus padres, y nacido el pretendiente, por la que hagan constar ser hijosdalgo notorios según las leyes de Castilla, limpios de sangre y de oficios mecánicos por ambas líneas.

\footnotetext{
${ }^{20}$ Bergarako Nobleen Errege Mintegiaren gobernurako Ordenantzak, 1818. Egileen itzulpena.

${ }^{21}$ Chaparro, A. (2011). Educarse para servir al Rey: El Real Seminario Patriótico de Vergara (1776-1804). Bilbo: Euskal Herriko Unibertsitatea (UPV/EHU).

${ }_{22}$ Bergarako Nobleen Errege Mintegiaren gobernurako Ordenantzak, 1818., 28. orr.
} 
Quedan excluidos de este envío quienes sean descendientes de un Caballero de la Orden de Carlos III, así como hijo de un Teniente Coronel o militar de superior grado, para lo cual solo tendrán que presentar justificante de ello» ${ }^{23}$.

Aipatutako Ordenantzek kanpoko ikasle zirenen funtzionamendu arauak ere zehazten zituzten: halako ikasleek, eskoletara joan ahal izateko, zuzendariaren baimena beharrezkoa zuten. Behin eskola-orduetan, ikasle guztiek - barne-ikasleek zein kanpokoek - arau berdinak errespetatu behar zituzten; azterketetara aurkezteko aukera zuten, baina kanpokoak ezin ziren sari-sisteman sartu ${ }^{24}$. Ordenantzek hezkuntza sistema arautu eta egituratu baten berri eskaintzen zuten, hainbat aipuk frogatzen duten bezala: «el que venga al Seminario después de haber comenzado los estudios, sufrirá un examen, para que acreditados los conocimientos que tiene, se le señale la clase en que debe continuar su instrucción» ${ }^{25}$. Ikasturtea hasierako hitzaldiaren irakurketarekin hasten zen eta uztailaren erdialdera arte irauten zuen.

XIX. mendearen lehen erdialdean jazotako gertakari historikoen gorabeherek oztopatu zuten araudi eta kudeaketa sistema berri baten bitartez egonkortasuna bilatzen zuen hezkuntza ikastegia egonkortzea; lehen itxiera gertatu baino hogeita hamar urte beranduago, Bergarako Mintegiak, euskal probintzietan zegoen gerra-egoeraren ondorioz, bere jarduera berriz ere bertan behera utzi behar izan zuen. 1835ean, gerra karlistaren ondorioz, Mintegiak jarduera akademikoa gelditu behar izan zuen eta bere ikasgelak ospital militar gisa erabili ziren.

Bost urte beranduago, 1840an, ikastegiak berriz ere ateak zabaldu zituen jarduera akademikoa berreskuratzeko. Aipatutako datan eraldatze garrantzitsuei ekin behar izan zien, espezializazio berria ekarriko zuten industria-ikasketak eta merkataritza-ikasketak martxan jartzeko. Berrogeita hamarreko hamarkadan, ikastegia Bigarren Hezkuntzako Gipuzkoako Institutu izatetik Zientzia eta Industria Eskola eta Ikastetxe Politeknikoa izatera pasa zen; horrela, hamarkadaren bukaeran, ikastegi mota berri batez eta, ondorioz, izen berri batez, hitz egin behar da: Real Seminario Científico e Industrial de Vergara delakoa, bi eskola barne hartu zituena: Matematikako Eskola Berezia eta Merkataritza Eskola. Eraldatze hauek Espainian 1850an ezarri zen Seijas Legeak ekarri zuen irakaskuntza eskema organikoaren eta zentralizatuaren menpe gertatu ziren.

1861. urtea ailegatuta, Gipuzkoako Aldundiak ikastegian eskaintzen ziren irakaskuntza bereziak mantentzea ahalbidetzen zuten dirulaguntza pu-

23 Idem.

${ }^{24}$ Bergarako Nobleen Errege Mintegiaren gobernurako Ordenantzak, 1818., 102103 orr.

${ }^{25}$ Idem. 
blikoak kentzea erabaki zuen; beraz, irakaskuntza zientifiko eta industrialak kendu ziren eta, salbuespenezko egoeran, merkataritza ikasketak 1873 arte mantendu ziren. Hurrengo urteetan hezkuntza ikastegiak aurrera egin zuen eta jarraitutasuna erakutsi zuen; hala ere, erakutsi zuen profil aldaketak XVIII. mendeko bigarren erdialdean sortutakoaren ilustrazio-jatorritik aldentzen zen ikastegi ezberdin batez hitz egitea zekarren.

\section{BERGARAKO MINTEGIAREN IKASLEAK 1776 ETA 1860 BITARTEAN}

Ikastegiko ikasleen analisiarekin hasita, interesgarria da horien jaioterriari erreparatzea, horren bitartez ikastegiko izaeraren berri ematen duten datu interesgarriak lortzen baitira; honela, 1776-1860 urte bitarteko epean, gehien errepikatzen zen jaioterria Madril zen, horren atzetik Habana eta Cádiz zetozela; esan bezala, datu adierazgarriak dira, ezin baita ahaztu hiri garrantzitsuenetako batzuk zirela Aintzinako Erregimeneko Monarkian eta aro kolonialaren amaiera arte. Hiru hiri horien atzetik euskal probintzietako hiriburuak agertzen dira.

1. taula

Mintegiko ikasleen jaioterri nagusiak (1776-1860)

\begin{tabular}{lc}
\hline \multicolumn{1}{c}{ Jaioterria } & Ikasle kopurua \\
\hline Madril & 97 \\
Habana & 57 \\
Cádiz & 55 \\
Bilbo & 52 \\
Donostia & 48 \\
Gasteiz & 35 \\
\hline
\end{tabular}

Iturria: VUA, 1975. orri-sorta.

Ikasleen analisia probintziaka edo lurraldeka eginez gero, aldaketa interesgarriak ikus daitezke. Jarraian eskaintzen den koadroak erakusten duenez, ikasle gehien biltzen zituen probintzia Gipuzkoa da - Mintegiko kokalekua-, eta jarraian Andaluzia, Bizkaia eta Madril agertzen dira; zerrendan Nafarroa ere agertzen da, ikasle kopuru esanguratsua erakusten baitzuen. Probintzia hauen atzetik, Kuba agertzen da, 72 ikasle zituela. Datu hauek berriz ere egiaztatzen dute ikuspegi politiko eta ekonomikotik, Monarkiaren lurralde garrantzitsuek ikasle-presentzia handia dutela Bergarako Mintegian. 


\section{2. taula}

Mintegiko ikasleen jaioterri-lurralde nagusiak

(1776-1860)

\begin{tabular}{lc}
\hline \multicolumn{1}{c}{ Lurraldea } & Ikasle kopurua \\
\hline Gipuzkoa & 149 \\
Andaluzia & 136 \\
Bizkaia & 116 \\
Madril & 103 \\
Nafarroa & 83 \\
Kuba & 72 \\
\hline
\end{tabular}

Iturria: VUA, 1975. orri-sorta.

Eskainitako datuak ikastegiaren izaeraz eta profil sozialaz jabetzeko baliagarriak izanik, onartu behar da analisia ikuspegi kronologiko estu batetik fokatzeak ikastegiaren ikuspegi globala eskuratzea oztopatzen duela. Ikerlan honetan, hasieran azpimarratu den bezala, objektutik aldentzea eta, era horretan, osotasunari erreparatzea bilatzen da. Horregatik, ikuspegia zabaltzeko asmoz, analisirako objektu bakarrean zentratzea hobetsi da: Bergarako Mintegia eta hango ikasle izan zirenak. Honela, ikasle kopuruen analisiak ikastegiaren garapenaren berri eskaintzen du. Ikasleen jaioterriaren gaineko datu osoak zehazki ezagutu arte kopuruek hainbat gorabehera erakusten badute ere, lehenengo hurbilpenak datu adierazgarriak uzten ditu.

3. taula

Ikasleen jatorri geografikoa garairik garai

\begin{tabular}{lc|lc|lc}
\hline \multicolumn{1}{c|}{ 1776-1804 } & $\begin{array}{c}\text { Ikasle } \\
\text { kopurua }\end{array}$ & 1804-1834 & $\begin{array}{c}\text { Ikasle } \\
\text { kopurua }\end{array}$ & 1840-1860 & $\begin{array}{c}\text { Ikasle } \\
\text { kopurua }\end{array}$ \\
\hline Madril & 39 & Madril & 42 & Donostia & 19 \\
Cádiz & 36 & Bilbo & 11 & Habana & 18 \\
Habana & 33 & Gasteiz & 10 & Madril & 16 \\
Bilbo & 26 & Donostia & 10 & Bilbo & 15 \\
Donostia & 19 & Cádiz & 9 & Gasteiz & 12 \\
Gasteiz & 13 & Bergara & 8 & Cádiz & 10 \\
Iruña & 10 & Burgos & 8 & Zaragoza & 8 \\
Tutera & 9 & Iruñea & 7 & Hondarribia & 7 \\
Durango & 8 & Coruña & 7 & Lima & 7 \\
El Ferrol & 8 & Panama & 6 & Iruñea & 7 \\
\hline
\end{tabular}

Iturria: VUA, 1975. orri-sorta eta AAG, 6541. orri-sorta. 
Ikastegia sortu zenetik, «Real Seminario Patriótico de Vergara»izenaz eta Euskalerriaren Elkarteak kudeatuta, ikasleak jaso zituen Espainiako Monarkiaren hiru hiri nagusietatik - Madril, Cádiz eta Habana-; horiek ziren, hain zuzen, sostengu politikoa eta ekonomikoa eskaintzen zuten hiriak. Hiru hiri horiek, geografikoki, euskal probintzietatik urrun zeuden, eta haietan Estatuko hainbat alderditan - Gortea, merkataritza, militaritza eta Administrazioa - nabarmentzen ziren kideak bizi ziren. Bergarako Mintegiak alderdi haietatik etorri ziren ikasle kopuru esanguratsu bat hartzeak, maila sozial altuen ondorengoen errekrutatze-ikastegi bihurtzen du. Horrez gain, ikastegia euskal probintzietan jaiotako umeen eta gazteen formaziorako lekua zela sostengatzen zuten zenbait teoriak esandakoaren kontra, ikastegiaren izaera zabalaren adierazgarri ere bada. Aipatutako hiru hiri nagusien eta euskal probintzietako hiriburuen atzetik, adierazgarria da geografikoki ikastegitik urrutiegi kokatuta ez zeuden hirien presentzia: El Ferrolek, adibidez, ikastegi pedagogikoekin erlazioa erakusten zuen, mendearen azken herenetik aurrera Itsasoko Guardiaren Sail bat hantxe kokatua baitzuen.

Bigarren garai nagusia ikastegiko titularitate aldaketarekin hasi zen, ikastegia Erregearen - bere Idazkari Nagusiaren - menpe geratu zenean. Garai horretan, aurretik eskainitako koadroak erakusten duen bezala, nabarmentzen da Madrilek erakusten duen nagusitasuna ikastegiko ikasle kopuruari dagokionez. Beste datu adierazgarri batzuen artean, azpimarratzekoa da 1804-1834 urte bitartean Habanak ikaslerik ez edukitzea, baina mende hasierako gerra-gertakariak kontuan hartuz gero, nahiko justifikagarria den datua da; horrez gain, Kubak erakusten zuen aldakortasun politikoa gazteen hezkuntza-gurariak oztopatzeko beste arrazoi bat zen. Hiru euskal hiriburuen presentziak, Madrilekin alderatu ezean, ez du atentzioa ematen. Azkenik, azpimarratzekoa da beste hirigune nabarmen batzuen agerpena, hala nola Iruñea, Coruña eta Burgos; horien ondoan, demografikoki apalagoak diren lurraldeen presentzia: Durango, Tutera eta lehen aldiz agertzen den Bergara bera.

Hirugarren garaian, berriz ere aldaketa esanguratsu bat egiazta daiteke, ikastegira zihoazen ikasle gehienak Donostiakoak baitziren. Ordu arte gertatzen zen bezala, Bilbo, Gasteiz, Cádiz eta Madril ikastegiaren sostengu nagusi bezala agertzen dira; era berean, esanguratsuak dira Madriletik etorritako ikasle kopuruaren jaitsiera eta Habanatik etorritako ikasle kopuruaren igoera.

Bestelako datu orokorrei begira, azpimarratu behar da nahiko ohikoa zela Bergarako Mintegitik familia beraren belaunaldi ezberdinak pasatzea. Batzuetan, ikasleen ehuneko-analisi soilak errealitatetik aldentzen diren hausnarketa okerrak ekar ditzake; hori dela eta, jarraian agertzen den taulan, Mintegiko ikasleen jatorrizko lekuen araberako ehuneko-analisia eta hamar mila biztanle bakoitzeko populazio-indizea eskaintzen da. 
4. taula

Bergarako Mintegiko ikasleen jaioterria

\begin{tabular}{|c|c|c|c|c|c|c|c|c|}
\hline & \multicolumn{3}{|c|}{ 1776-1824 } & \multicolumn{3}{|c|}{$1825-1860$} & \multicolumn{2}{|c|}{ Totales } \\
\hline & $\begin{array}{c}\text { Kasu } \\
\text { kopurua }\end{array}$ & $\%$ & $\begin{array}{c}\text { Indizea } \\
(1797)\end{array}$ & $\begin{array}{c}\text { Kasu } \\
\text { kopurua }\end{array}$ & $\%$ & $\begin{array}{c}\text { Indizea } \\
(1857)\end{array}$ & $\begin{array}{c}\text { Kasu } \\
\text { kopurua }\end{array}$ & $\%$ \\
\hline Andaluzia & 105 & 14,2 & 0,55 & 35 & 13,1 & 0,11 & 140 & 13,93 \\
\hline Aragoi & 15 & 2 & 0,22 & 15 & 5,6 & 0,17 & 30 & 2,99 \\
\hline Asturias & 13 & 1,8 & 0,35 & 6 & 2,2 & 0,11 & 19 & 1,89 \\
\hline Balearrak & 3 & 0,4 & 0,16 & 0 & 0 & 0 & 3 & 0,30 \\
\hline Kanariak & 1 & 0,1 & 0,05 & 4 & 1,5 & 0,17 & 5 & 0,50 \\
\hline Kantabria & 26 & 3,5 & 1,44 & 12 & 4,5 & 0,56 & 38 & 3,78 \\
\hline Gaztela-Mantxa & 10 & 1,3 & 0,10 & 5 & 1,9 & 0,04 & 15 & 1,49 \\
\hline Gaztela eta Leon & 67 & 9,1 & 0,35 & 16 & 5,9 & 0,07 & 83 & 8,26 \\
\hline Katalunia & 8 & 1,1 & 0,09 & 4 & 1,5 & 0,02 & 12 & 1,19 \\
\hline Ceuta & 2 & 0,3 & 3,81 & 0 & 0,8 & 0 & 2 & 0,20 \\
\hline Extremadura & 18 & 2,4 & 0,42 & 2 & 1,1 & 0,028 & 20 & 1,99 \\
\hline Galizia & 36 & 4,9 & 0,31 & 3 & 7,5 & 0,01 & 39 & 3,88 \\
\hline Madril & 83 & 11,3 & 3,46 & 20 & 2,2 & 0,4 & 103 & 10,25 \\
\hline Murtzia & 6 & 0,8 & 0,15 & 6 & 5,9 & 0,15 & 12 & 1,19 \\
\hline Nafarroa & 67 & 9,1 & 3,02 & 16 & 0 & 0,53 & 83 & 8,26 \\
\hline Errioxa & 39 & 5,3 & 2,60 & 11 & 4,1 & 0,63 & 50 & 4,98 \\
\hline Valentzia & 5 & 0,7 & 0,06 & 1 & 0,4 & 0,008 & 6 & 0,60 \\
\hline $\begin{array}{l}\text { Araba, Bizkaia eta Gi- } \\
\text { puzkoa }\end{array}$ & 233 & 31,6 & 8,22 & 112 & 41,8 & 2,700 & 345 & 34,33 \\
\hline Guztira & 737 & 100,0 & & 268 & 100,0 & & 1.005 & 100,00 \\
\hline
\end{tabular}

Iturria: Martínez, J. (1972). Filiación de los seminaristas del Real Seminario Patriótico Bascongado y de Nobles de Vergara. Donostia: Euskalerriaren Adiskideen Elkartea.

Taulak eskaintzen dituen datuak aztertu ondoren, badaude bereziki azpimarratzekoak diren zenbait alderdi: lehenik, euskal probintziek erakusten zuten nagusitasuna, beste probintziekin alderatuta, bigarren garaian areagotu egiten dena. Era berean, Andaluziako kasua azpimarratzekoa da: lurralde honek Mintegian erakusten zuen ikasle kopuruari erreparatuz gero, - euskal probintzien atzetik - geografikoki ordezkatuen zegoen bigarren lurraldea zen; ehunekoari begira, beste batzuekin alderatuta, nabarmentzen zen. Hala ere, hamar mila biztanleko Bergarako Mintegira zihoan gazte kopuruari erreparatuz, zerrendako postua eta zenbakia era esanguratsuan aldatu egiten dira: Andaluzia, Madril, Nafarroa eta Kantabriaren atzetik geratzen da eta, bigarren garaian, Aragoi, Kanaria edo Murtziaren atzetik. Azpimarratzekoa da, baita ere, Madrilek erakusten duen garapen negatiboa, populazio-indizean hirugarren postutik bosgarrenera pasatzen baita, ikasle kopuruaren jaitsiera nabarmena erakutsiz; bigarren garaia laburragoa bada ere, ehun ikasle inguru izatetik hogei ikasle izatera pasa zen. 


\section{MINTEGIA ITXI ONDOREN IKASTEGIAN SARTZEN ZIREN IKASLEAK ETA BEREN OHITURAK}

Bergarako Mintegiak, gerrako gertakarien ondorioz, bere ateak bi aldiz itxi behar izan zituen; bietan irakasleek zein ikasleek beste lurralde batzuetara ihes egin zuten bakearen bila. Era berean, gerrak ekarritako zailtasun ekonomikoak eta sozialak behin gaindituta, bi aldietan ikastegia berriz zabaltzearen aldeko apustua egin zen. Ikasleen jatorria aztertzeak ikastegiaren sostengu zirenen berri ematen digu: 1798an, Konbentzio Gerrak ekarritako itxiera garaian, hogeita bat ikasle berriren jaioterria aztertuta, horietatik hamalau euskal probintzietakoak ziren, bederatzi Gipuzkoakoak izanik. Aipatzekoa da, era berean, euskal lurraldeen inguruko probintzietatik zetozen hiru ikasleen kasua; azkenik, Madriletik hiru ikasle eta Habanatik ikasle bakarra etorri ziren.

1840 urteari dagokionez, ikasle gehienen jaioterrien datuak ez dira ezagutzen; hala ere, ezagutu diren datuek ikasleen profilari buruzko informazioa eskaintzen dute: Bergarako Mintegia zabaldu ondorengo bi urteetan bi gipuzkoar eta hiru bizkaitar sartu ziren bertan; horrek erakusten du urte horietan hezkuntza-ikastegiak eskualdean bertan zuela bere sostengu, eta beharrezkoa zela hezkuntza-egitasmoa bultzatzea Bergaratik urrun kokatutako lurraldeen ikasleak erakartzeko.

Mintegi barruan, araututako erakunde baten menpe zeuden ikasleak garaiko hezkuntza eta politika testuinguruaren beharretara egokitzen joan ziren Ordenantza batzuen arabera egituratuta zegoen erakunde baten menpe. Horregatik, egonaldia ikastegian urte batzuez luzatuko zen, beren heziketa osatu arte. Ikasleen iraute-datuen analisiak datu interesgarriak eskaintzen ditu: 1776 eta 1804 urte bitarteko garaian, egonaldia nekez ailegatu ohi zen hiru urtera; hurrengo garaian -1776 eta 1804 urteen bitartean - ematen zena baino motzagoa. Azkenik, 1840 eta 1860 urte bitartean, egonaldia bi urte ingurukoa izaten zen; honek sistema pedagogikoaren aldaketaren berri ematen du, beste ikasketa batzuk osatzeko baliagarria izango zen espezializazioa eskaintzeari orientatu zena.

Jarraian eskaintzen den taulak Bergarako ikastegiko ikasleen sarrera eta irteera datuak ezagutzea ahalbidetzen du. Ordenantza batzuen arabera egituratuta zegoen ikastegia izan arren, errealitateak erakusten du araututako hainbat alderdi, hala nola ikasturtearen hasiera eta bukaera, inguruabarren menpe geratu ohi zirela. Horrela, bada, sarrerak eta irteerak gehienbat araututako datetan - iraila eta urria sarreretarako eta uztaila eta abuztua irteeretarako - ematen baziren ere, egiazta daiteke lehenengo bi garaietan urte osoan zehar gertatzen zirela, Ordenantzek adierazitakoa errespetatu gabe. 1840 eta 1860 urteen bitartean joera era esanguratsuan aldatzen da: ikastegirako sarrerak uda ondorengo hilabeteetan eta irteerak uda hasieran egonkortu egiten dira. 
5. taula

Ikasleen sarrera eta irteera datuak garairik garai

\begin{tabular}{|c|c|c|c|c|c|c|c|c|c|c|c|c|}
\hline & \multicolumn{4}{|c|}{$1776-1804$} & \multicolumn{4}{|c|}{$1804-1834$} & \multicolumn{4}{|c|}{$1840-1860$} \\
\hline & \multicolumn{2}{|c|}{ Sarrerak } & \multicolumn{2}{|c|}{ Irteerak } & \multicolumn{2}{|c|}{ Sarrerak } & \multicolumn{2}{|c|}{ Irteerak } & \multicolumn{2}{|c|}{ Sarrerak } & \multicolumn{2}{|c|}{ Irteerak } \\
\hline & $\begin{array}{c}\text { Kasu } \\
\text { kopurua }\end{array}$ & $\%$ & $\begin{array}{c}\text { Kasu } \\
\text { kopurua }\end{array}$ & $\%$ & $\begin{array}{c}\text { Kasu } \\
\text { kopurua }\end{array}$ & $\%$ & $\begin{array}{c}\text { Kasu } \\
\text { kopurua }\end{array}$ & $\%$ & $\begin{array}{c}\text { Kasu } \\
\text { kopurua }\end{array}$ & $\%$ & $\begin{array}{c}\text { Kasu } \\
\text { kopurua }\end{array}$ & $\%$ \\
\hline Urtarrila & 37 & 7,21 & 20 & 4,58 & 27 & 5,64 & 18 & 3,95 & 14 & 8,33 & 1 & 0,92 \\
\hline Otsaila & 23 & 4,47 & 18 & 4,12 & 19 & 3,97 & 24 & 5,26 & 0 & 0,00 & 1 & 0,92 \\
\hline Martxoa & 20 & 3,89 & 26 & 5,95 & 24 & 5,01 & 17 & 3,73 & 5 & 2,98 & 0 & 0,00 \\
\hline Apirila & 32 & 6,23 & 35 & 8,01 & 35 & 7,31 & 45 & 9,87 & 6 & 3,57 & 4 & 3,67 \\
\hline Maiatza & 39 & 7,59 & 33 & 7,55 & 54 & 11,27 & 22 & 4,82 & 2 & 1,19 & 1 & 0,92 \\
\hline Ekaina & 49 & 9,53 & 34 & 7,78 & 38 & 7,93 & 32 & 7,02 & 5 & 2,98 & 27 & 24,77 \\
\hline Uztaila & 25 & 4,86 & 47 & 10,76 & 31 & 6,47 & 130 & 28,51 & 6 & 3,57 & 34 & 31,19 \\
\hline Abuztua & 34 & 6,61 & 95 & 21,74 & 34 & 7,11 & 71 & 15,57 & 8 & 4,76 & 18 & 16,51 \\
\hline Iraila & 65 & 12,65 & 40 & 9,15 & 71 & 14,82 & 34 & 7,46 & 46 & 27,38 & 4 & 3,67 \\
\hline Urria & 95 & 18,48 & 41 & 9,38 & 86 & 17,95 & 16 & 3,51 & 54 & 32,14 & 7 & 6,42 \\
\hline Azaroa & 66 & 12,84 & 20 & 4,58 & 36 & 7,52 & 12 & 2,63 & 20 & 11,91 & 3 & 2,75 \\
\hline Abendua & 29 & 5,64 & 28 & 6,41 & 24 & 5,01 & 35 & 7,68 & 2 & 1,19 & 9 & 8,26 \\
\hline Guztira & 514 & 100,00 & 437 & 100,00 & 479 & 100,00 & 456 & 100,00 & 168 & 100,00 & 109 & 100,00 \\
\hline
\end{tabular}

Iturria: VUA, 1975. orri-sorta eta AAG, 6541. orri-sorta.

Hezkuntza ikastegian ikasleak Erregeak agindutako irakaskuntzak gauzatzen zituzten; beren egonaldia, heziketa eta irautea ikastegiaren kudeaketa organoak bultzatutako aldarrikapen politikoekiko kide izatearen konotazioak zekartzan. Hezkuntza ikastegi batekiko uztartzeak, ezagutzak barneratze soilak baino inplikazio sakonagoak erakutsi behar zituen ${ }^{26}$.

\section{ONDORIOAK}

Ezaguna da Gipuzkoako hezkuntza-panoramikan Bergarak erakutsi zuen garrantzia eta ospea. Ikerlan honetan aztertzen den Bergarako Mintegiaren sorrera Espainiako hezkuntzaren historiako une garrantzitsu batean eman zen; ordurarte Elizak hezkuntzan erakusten zuen nagusitasuna ahuldu zen, hortik aurrera Estatua izanik autoritatea eskuratu zuena. Horren adierazle nagusia 1767an eman zen jesuiten kanporaketa izan zen. XVIII. mendea erabakigarria izan zen Bergarako irakas-ospea areagotzeko prozesuan;

${ }^{26}$ Chaparro, A. (2013). Educación y fidelización política: los seminarios de nobles en la España del siglo XVIII in Franco, G. (ed.). Vínculos y sociabilidades: reflexiones desde el Bicentenario de las Guerras de Independencia en España e Iberoamérica. Madril, 207-225. 
horretan, azpimarratzekoa da Euskalerriaren Adiskideen Elkarteak - eta bereziki Xavier María de Munibek, Peñafloridako Kondeak - egin zuen lana. Jesuiten kanporaketa eman ondoren, lan handia egin zuen ordurarte kongregazio erlijiosoak Bergaran okupatutako hornikuntzak eskuratzeko; bi urte beranduago bere helburua lortu zuen. Lehenengo lorpenaz gain, 1771 urtean beste lorpen garrantzitsu bat eman zen, Euskalerriaren Adiskideen Elkarteak Carlos III Erregearen babesa eskuratu baitzuen.

Ikuspegi pedagogikotik, Bergarako Mintegiaren analisiak oroimenean oinarritutako ikasketetatik ikasketa teknikoetara eta, ondoren, industrialetara igarotzeko prozesua ezagutzea ahalbidetzen du. Prozesu horretan, 1850 urtea azpimarratzekoa den data da, urte horretako irailaren 4ko dekretu batek Espainian industria-eskolak ezartzeko beharra adierazi baitzuen; dekretu horrek, industria-irakaskuntza motak zehazteaz gain, eskolak kokatzeko lekuak ere zehaztu zituen: sakontzeko ikasketak, dekretuak ezarritakoaren arabera, Bartzelonan, Sevillan eta Bergaran eskaini behar ziren. Beraz, honek Bergarak ordurako bereganatua zuen ospearen beste ebidentzia bat eskaintzen digu. Horrez gain, Bergarako kasua oso lagungarria da hezkuntza ikastegien garapena ezagutu ahal izateko ikuspegi kronologiko zabal batetik. Gertakari historikoen menpe, hezkuntza ikastegiek nahitaez eboluzionatu behar zuten, garai bakoitzeko errealitatera eta testuinguru historikoaren ondorio politikoetara eta ekonomikoetara egokitu ahal izateko.

Kronologikoki etenak egiten dituzten ikerlanek ikastegien ikuspegi historiko osoa ezagutzea oztopatzen dute. Bergarako Mintegiaren kasuan - gertakari historikoen ondorioz - ikastegiari hainbat izen ezberdinez deitzeak beste hainbeste ikastegi desberdin direla pentsaraz dezake baina, errealitatean, jatorrizko ikastegiaren bilakaeraren berri ematen digu izen multzokada horrek, garai bakoitzeko beharretara egokitu behar izan dena. Honela, eraikin fisikoa baino, horren partaide izan ziren lagunen ezaugarriak ezagutu nahi izan dira; beren erabakietan eta ohituretan emandako aldaketak ezagutzea beharrezkoa da, horiek baitira ikastegiak garairik garai erakusten duen lotura ezagutzeko modurik onena. Lan honetan eskainitako datuen bidez egiazta daiteke ikastegiaren ospeak probintzia eta lurralde ugarietako ikasleak erakartzen zituela eta, oro har, ikuspegi politiko eta ekonomikotik adierazgarrienak ziren lurraldeek ikasle kopuru handia zutela Bergarako Mintegian. Ikastegiak Gortean, merkataritzan, militaritzan eta Administrazioan ospea erakusten zuten hainbat pertsonaren semeak erakarri zituen. Beraz, egiaztatzen da maila sozial altuek, beren ondorengoak hezteko garaian, konfiantza jartzen zutela Bergarako ikastegian. Ikastegiak ia ehun urte iraun zuen, eta urte horietan zehar etengabeko eraldaketan zegoen gizartearen gorabehera politikoei, sozialei eta ekonomikoei erantzun behar izan zien.

Ikerlan honek etorkizunari begirako hainbat erronka uzten dizkigu: horien artean, interesgarria izango da aztertzea zergatik familia batzuek, nahiz eta erakundearen izena aldatu, era berdinean jokatzen jarraitzen zuten. Bigarren hipotesiak familia horien fideltasuna azpimarratzen zuen, fa- 
miliek erakusten baitzuten erakundeen izenetatik eta kokalekuetatik harago zihoan zerbait bazegoela.

\begin{abstract}
Historical events definitely affect the life of educational institutions. In the case of the Royal Seminar of Vergara, some one hundred years of history saw the intervention of many different military, political, social and economic situations that threw this institution into a constant process of adjustment and variation. In this work, we aim at approaching a wider perspective on the study of this process, avoiding previous fragmented or partial angles. We consider that, in spite of the nominative changes or the alterations in the pedagogic profile of the Seminar, we are still before the same institution and it will remain the same from the $18^{\text {th }}$ Century up to the mid-19th Century. To observe with major detail the evolution of this school, we have decided to focus our attention on the students, that is to say, on the principal agents of the institution. Through our penetrating examination of their biographies, we are able to discern if those historical changes that affected the institution did also alter the social profile of the students or, on the contrary, the Royal Seminar of Vergara kept being the first option for those families that had traditionally sent their children to this institution in order to provide them with an appropriate education.
\end{abstract}

Keywords: Gipuzkoa, Bergara, Seminar, secondary education, institute.

La villa de Vergara fue el lugar donde se situaron los orígenes del Instituto Provincial de Segunda Enseñanza, un hecho que no resulta casual, puesto que la citada villa se erigió en una referencia obligada en cuanto a tradición docente. Indudablemente, la Real Sociedad Bascongada de Amigos del País (RSBAP), fundada por Xavier María de Munibe -Conde de Peñaflorida- es el principal referente de la configuración educativa de la villa. El Real Seminario de Vergara representó uno de los centros educativos de referencia, principalmente a lo largo del Antiguo Régimen; indudablemente, dicho establecimiento representó uno de los principales baluartes de la renovación educativa de la época, atrayendo a un considerable número de alumnos de los territorios políticamente y económicamente más representativos. El presente estudio pretende abordar una visión global del estable- 
cimiento, otorgando protagonismo a los individuos que lo han ido conformando. El análisis de la parte viva del centro, representada principalmente por el alumnado, posibilita adentrarse en el núcleo del mismo e ir conociendo su evolución, así como la forma en que debió responder a las coyunturas históricas a las que debió enfrentarse en el periodo de 1776 a 1860 .

Palabras clave: Gipuzkoa, Bergara, Seminario, segunda enseñanza, instituto.

Les événements historiques altèrent, d'une manière remarquable, la vie d'une institution éducative. Pour le Séminaire de Vergara, l'objet central de cet étude, ont été nombreuses les situations de guerre, ainsi que politiques, sociales et économiques qui, depuis la fondation de l'institution, ont provoqué des changements dans l'organisation de cet établissement. Notamment, nous essayons ici de nous éloigner des études qui fragmentent l'analyse des institutions enseignantes en fonction des événements historiques pour aborder une étude depuis une plus ample perspective. Nous considérons que, malgré les changements nominatifs ou les altérations dans le profil pédagogique du Séminaire, pour le cas de Vergara nous sommes devant la même institution depuis la fin du XVIIIe siècle jusqu'à la moitié du XIXe siècle. Afin de pouvoir observer, avec plus de détail, l'évolution du centre éducatif nous avons choisi de pointer notre attention sur les agents principaux de l'institution, les élèves. La possibilité qu'on a eu de connaître ses trajectoires vitales nous aident à entendre si les la sphère historique a apporté des modifications dans le profil social de l'établissement ou si, en revanche, celui-ci a continué à se montrer comme l'option préférentielle pour les familles qui avaient traditionnellement décidé élever ses enfants à la dite institution.

Mots clé: Gipuzkoa, Bergara, Séminaire, éducation secondaire, institut.

\section{ERREFERENTZIAK}

Aguilar, F. (1980). Los Reales Seminarios españoles en la política ilustrada espanola. Cuadernos hispanoamericanos, 356, 329-349.

Caballer, M. C. (2008). La Escuela Especial de Matemáticas del Real Seminario Científico Industrial de Vergara. Llull, 31, 21-40.

Caballer, M. C. (2009). Los alumnos de la Escuela Especial de Matemáticas del Real Seminario Científico Industrial de Vergara. Llull, 32, 257-293.

Camino, I. (2012). El Instituto Provincial de Segunda Enseñanza de Guipúzcoa (1845-1901). Madril: Delta Publicaciones. 
Cano, J. (2000). La Escuela Industrial de Vergara (1848-1860). Historia Educación, Universidad de Salamanca, 19, 225-248.

Chaparro, A. (2011). Educarse para servir al Rey: El Real Seminario Patriótico de Vergara (1776-1804). Bilbo: Euskal Herriko Unibertsitatea (UPV/EHU).

Chaparro, Á. (2013). Educación y fidelización política: los seminarios de nobles en la España del siglo XVIII in Franco, G. (ed.). (2013). Vínculos y sociabilidades: reflexiones desde el Bicentenario de las Guerras de Independencia en España e Iberoamérica, 207-225. Madril.

Dedieu, J. P. (2000). Procesos y redes. La historia de las instituciones administrativas de la época moderna, hoy, in Castellano, Dedieu, J. P. eta López-Cordón, M.V. (edit.), La pluma, la mitra y la espada. Estudios de Historia Institucional en la Edad Moderna. 13-30.

Dedieu, J. P. (2005). La muerte del letrado in Aranda, F.J. (Koord.). Letrados, juristas y burócratas en la España Moderna. Cuenca: Universidad de Castilla La Mancha.

De Felipe, E. (1993). Los cien nombres del Seminario de Bergara (1776-1873). Nuevos Extractos de la Real Sociedad Bascongada de los Amigos del País, Boletín de la Real Sociedad Bascongada de los Amigos del País, 6-G, 13-69.

Imízcoz, J. M. eta Chaparro, A. (Koord) (2013). Educación, redes y producción de élites en el siglo XVIII. Madril: Silex.

Iriarte, J. (1953). Los estudios científicos en Vergara a fines del siglo XVIII. Donostia: Biblioteca Vascongada Amigos del País.

Larrañaga, K. (1991). Las manifestaciones del hecho ilustrado en Bergara. Bergara: Bergarako Udaletxea.

Letamendia, R. M. (1987). Ideario pedagógico de la Real Sociedad Bascongada de los Amigos del País y sus realizaciones en Álava. Boletín R.S.B.A.P., Año XLIII, 21-135.

Martínez, J. (1972). Filiación de los seminaristas del Real Seminario Patriótico Bascongado y de Nobles de Vergara. Donostia: Euskalerriaren Adiskideen Elkartea.

Mendiola, Rufino (1961). Los estudios en el Real Seminario de Vergara. Bergara: Instituto laboral, padres dominicos.

Pellón, I. eta Llombart, J. (1998). La formación científica recibida en el Real Seminario Bascongado por los estudiantes riojanos, in Español, L. (Koord.) $M a-$ temática y región: La Rioja: sobre matemáticos y matemática en La Rioja. Logroño: Instituto de Estudios Riojano, 343-368.

Recarte, M. T. (1990). Ilustración vasca y renovación educativa: La Real Sociedad Bascongada de los Amigos del País. Salamanca: Universidad Pontificia de Salamanca, Real Sociedad Bascongada de los Amigos del País.

San Larrañaga, K. (1991). Las manifestaciones del hecho ilustrado en Bergara. Bergara: Bergarako Udaletxea.

Silván, L. (1977). Los estudios científicos en Vergara a fines del siglo XVIII. Donostia: Biblioteca Vascongada de Amigos del País.

Tellechea, J. I. (1977). Documentos sobre la crisis de 1804 del Real seminario de Vergara, Boletín RSBAP, 33, 109-145.

Yoldi, F. (1945). El aislamiento del platino y el Real Seminario de Vergara, Anales de la Sociedad Española de Física y Química, 195-212.

Yrizar, J. (1945). El Real Seminario de Vergara», Boletín R.S.B.A.P., 1, 301-311. 